\title{
BODY MASS INDEX AND URINALYSIS MARKERS IN THE SEEMINGLY HEALTHY YOUNG ADULTS
}

\author{
Krisnawan Andy Pradana ${ }^{2}$, Viskasari P. Kalanjati ${ }^{1}$, Ni Wajan Tirthaningsih ${ }^{1}$ \\ ${ }^{1}$ Department of Anatomy and Histology, ${ }^{2}$ Faculty of Medicine, Universitas Airlangga, Surabaya, Indonesia
}

\begin{abstract}
Higher prevalence of albuminuria, glycosuria, and haematuria was reported in the obese people than control. We aimed to analyze the BMI and urinalysis markers among the university students aged 18-21 years old in the IIKBW, Kediri to study any correlations and differences between these variables, which to the best of our knowledge has yet widely reported in Indonesia. This study has ethics approval from Universitas Airlangga, Surabaya. The BMI was analyzed from the body weight and height of male $(n=74)$ and female $(n=76)$ students with no health problems recorded. The $p H$, nitrites, protein, erythrocytes, glucose in the urine were measured qualitatively with a dip-stick method, blinded, using the midstream urine sample collected in the morning. Data were analyzed using SPSS 17, with a level of significance of $p<0.05$. Abnormal $p H(n=75)$, positive nitrites $(n=24)$, haematuria $(n=6)$, and proteinuria $(n=149)$ were recorded. About $22 \%$ of students suffered from type I obesity, and $8.7 \%$ of type II. Males were significantly suffered from the obesity whilst females from the overweight $(p<0.05)$. No significant correlations between the BMI and each urinalysis marker (BMI and nitrites $p=0.936 ; B M I$ and protein $p=1 ; B M I$ and $p H$ $p=0.835 ;$ BMI and blood, $p=0.486$; respectively); no one were found with glycosuria. No significant differences either on the $B M I$ or the 5 urinalysis markers between male and female groups $(p>0.05)$. Whilst no positive glycosuria samples were identified; $18.9 \%$ of males and $13.2 \%$ of females have positive nitrites, $100 \%$ of males and $98.7 \%$ of females have positive proteinuria, $2.7 \%$ of males and $7.9 \%$ of females have positive haematuria. There were $7.33 \%$ of males and $6 \%$ of females having an increased $\mathrm{pH}$; whilst $20.66 \%$ of males and $16 \%$ of females having a decreased $\mathrm{pH}$. Amongst the seemingly healthy university students, we found cases of urinalysis marker impairment, although no significant correlations on the BMI to the urinalysis markers that may be representing early detection for renal diseases were observed.
\end{abstract}

Keywords: Urinalysis; anthropometry; renal health; students

\section{ABSTRAK}

Prevalensi albuminuria yang tinggi, glikosuria, hematuria dilaporkan pada penderita obesitas daripada kontrol. Penelitian ini bertujuan untuk menganalisis IMT dan urinalisis di kalangan mahasiswa berusia 18-21 tahun di IIKBW, Kediri; untuk mempelajari korelasi dan perbedaan antara variabel-variabel ini, yang sejauh pengetahuan kami belum banyak dilaporkan di Indonesia. Penelitian ini mendapat persetujuan etik dari Universitas Airlangga. IMT dianalisis dari berat badan dan tinggi badan siswa laki-laki $(n=74)$ dan perempuan $(n=76)$ tanpa masalah kesehatan yang tercatat. pH, nitrit, protein, eritrosit, glukosa dalam urin diukur secara kualitatif dengan metode dipstik, secara objektif, menggunakan sampel urin tengah yang dikumpulkan di pagi hari. Data dianalisis menggunakan SPSS 17, dengan tingkat signifikansi p <0,05. Sekitar $22 \%$ siswa menderita obesitas tipe I, dan 8,7\% dari tipe II. Laki-laki secara signifikan menderita obesitas sedangkan perempuan dari kelebihan berat badan ( $p<0,05$ ). Tidak ada korelasi yang signifikan antara BMI dan setiap penanda urinalisis (BMI dan nitrit $p=0.936 ;$ BMI dan protein $p=1 ;$ BMI dan $p H p=0.835 ;$ BMI dan darah, $p=0.486)$; tidak ditemukan kasus glikosuria. Tidak ada perbedaan signifikan baik pada BMI atau 5 penanda urinalisis antara kelompok pria dan wanita (p>0,05). Meskipun tidak ada yang terdeteksi glikosuria, $18,9 \%$ laki-laki dan 13,2\% perempuan terdeteksi dengan nitri positif, semua laki-laki dan $98,7 \%$ perempuan proteinuria, 2,7\% laki-laki dan 7,9\% peerempuan hematuria, 7,33\% laki-laki dan 6\% perempuan pH urin tinggi, 20,66\% laki-laki dan $16 \%$ perempuan memiliki pH urin lebih rendah dari nilai normal. Di antara mahasiswa yang tampaknya sehat, ditemukan adanya profil urinalisis yang abnormal, meskipun tidak ada korelasi yang signifikan antara BMI dengan masing-masing penanda urinalisis tersebut, sebagai deteksi dini adanya kelainan pada sistem urinarius.

Kata kunci: Urinalisis; antropometri; kesehatan ginjal; mahasiswa

Correspondence: Viskasari P. Kalanjati, Department of Anatomy and Histology, Faculty of Medicine, Universitas Airlangga, Surabaya, Indonesia. E-mail: viskasari-p-k@fk.unair.ac.id

pISSN:2355-8393 • eISSN: 2599-056x • doi: http://dx.doi.org/10.20473/fmi.v56i2.21233

- Fol Med Indones. 2020;56:135-139 • Received 31 Jul $2019 \bullet$ Accepted 9 Jan 2020

- Open access under CC-BY-NC-SA license • Available at https://e-journal.unair.ac.id/FMI/ 


\section{INTRODUCTION}

The occurrence of overweight and obesity representing by high body mass index (BMI) is increasing significantly worldwide, including among the young adults. The World Health Organization (WHO) determines overweight and obesity as abnormal or excessive fat accumulation that presents a risk to health (Xiang et al 2017, Zoccali \& Mallamaci 2011). The BMI may serve as an early indicator for these conditions. By the standard of the Asia-Pacific, BMI less than $18.5 \mathrm{~kg} / \mathrm{m}^{2}$ are classified as underweight, 18.5 $22.9 \mathrm{~kg} / \mathrm{m}^{2}$ are classified as normal weight, $23.0-24.9$ $\mathrm{kg} / \mathrm{m}^{2}$ are classified as overweight, $25.0-29.9 \mathrm{~kg} / \mathrm{m}^{2}$ are classified as obese I and BMI greater than or equal to 30 $\mathrm{kg} / \mathrm{m}^{2}$ are defined as obese II. The previous study has reported that excessive body weight might impair the renal function by compromising the water and electrolyte balance due to the muscle and fat ratio imbalance. The condition of obesity makes adipose cells in adipose tissue additions, both in terms of size and number (Xiang et al 2017, Zoccali \& Mallamaci, 2011).

Obesity can increase cortisol production levels (Hewagalamulage et al 2016). High cortisol production can disrupt the equilibrium of the 11ß-HSD enzyme that converts cortisol to cortisone (inactive form). If this imbalance continues, then the mineralocorticoid receptor, cortisol will be bound and then it will induce damage or provide a detrimental effect on organs such as the kidneys, heart and blood vessels that can be blocked by the antagonistic mechanism of the mineralocorticoid receptor (Gant et al 2018). When kidney function decreases, the glomerular filtration rate becomes abnormal and renin production, angiotensin III, aldosterone, and ADH will be disrupted (Cuzzo \& Lappin, 2019, Fountain \& Lappin, 2019, Scott \& Dunn, 2019).

Anomalous discovery in urinalysis can be found in 1$14 \%$ of healthy adolescents (Eidelman et al 2002, Lammers et al 2001, Smith et al 2003, Van Nostrand et al 2000). Dipstick urinalysis is regularly performed to analyze urinary tract infection which may affect the renal function. The dipstick test can be used to detect proteinuria, glycosuria, and haematuria. Study on the BMI and urinalysis profile has not widely reported in Indonesia, to the best of our knowledge. This study aimed to analyze the BMI and urinalysis markers amongst the university students aged 18-21 years old in the IIKBW, Kediri; to study any correlations and differences between these variables in seemingly healthy males and females, to determine the BMI and renal function amongst adolescent in Indonesia.

\section{MATERIALS AND METHODS}

The study was conducted in 74 male and 76 female students of the Faculty of Dentistry, Institut Ilmu Kesehatan Bhakti Wiyata (IIKBW), Kediri, East Java, Indonesia GED 18-22-year-old. Ethical clearance was obtained from the Research and Ethical Committee of Universitas Airlangga, Surabaya, Indonesia. After informed consent and information for consent were signed, all subjects were fasting overnight from 10.00 pm until the study began at approximately $07.00 \mathrm{am}$ in the next morning. The weight, height, waist circumference and hip circumference were measured using standard anthropometry. Body weight was measured to the nearest $0.1 \mathrm{~kg}$ using Omron HN289 (Omron, Japan) digital weighing scale placed on a firm, flat ground with subjects wearing light clothing and no shoes; belts and other accessories were removed and pockets emptied. Height was measured to the nearest $0.1 \mathrm{~cm}$ using a wall-mounted tape measure (GEA, Indonesia) with the subjects standing erect, barefoot, heels together and looking straight ahead in the Frankfurt plane. The BMI was calculated as weight in kilograms divided by height squared in meters. Subjects with BMI of less than $18.5 \mathrm{~kg} / \mathrm{m}^{2}$ were classified as underweight, $18.5-22.9 \mathrm{~kg} / \mathrm{m}^{2}$ were classified as normal weight, $23.0-24.9 \mathrm{~kg} / \mathrm{m}^{2}$ were classified as overweight, $25.0-29.9 \mathrm{~kg} / \mathrm{m}^{2}$ were classified as obese I and BMI greater than or equal to $30 \mathrm{~kg} / \mathrm{m}^{2}$ were defined as obese II. All measurements were in duplicate and blinded, analyzed from the midstream urine sample collected in the morning and collected in a sterile $15 \mathrm{cc}$ Falcon tube. The pHs, nitrites, protein, erythrocytes, glucose in the urine were measured qualitatively with a dip-stick method (Verify, Acon Biotech, China). Data were analyzed using SPSS 17, with a level of significance of $\mathrm{p}<0.05$ (Tables 1-3).

\section{RESULTS}

The BMI and urinalysis markers of $\mathrm{pH}$, nitrites, blood, protein, and glucose among male and female are detailed in Table 1. About $22 \%$ of students suffered from type I obesity, and $8.7 \%$ of type II. Males were significantly higher than females to suffer from type I obesity ( $\mathrm{p}=0.004 ; 32.4 \%$ males vs. $11.8 \%$ females). On other hand, no significant difference in the type II obesity ( $\mathrm{p}=1 ; \quad 8.1 \%$ males and $9.2 \%$ females). Overweight is detected in $18 \%$ of total students with a significant difference between males and females ( $\mathrm{p}=0.04 ; 10.8 \%$ in males, $25 \%$ in females). However, no significant differences in BMI between males and females $(\mathrm{p}=0.41)$. Whilst no positive glycosuria samples were identified; approximately $18.9 \%$ of males $(n=14)$ and $13.2 \%$ of females $(n=10)$ have positive nitrites, 
$100 \%$ of males $(n=74)$ and $98.7 \%(n=75)$ of females have positive proteinuria, $2.7 \%$ of males $(n=2)$ and $7.9 \%$ of females $(n=4)$ have positive haematuria. There are $7.33 \%(n=11)$ of males and $6 \%(n=9)$ of females have an increased $\mathrm{pH}$; whilst $20.66 \%(\mathrm{n}=31)$ of males and $16 \%(n=24)$ of females have a decreased $\mathrm{pH}$.
There are no significant correlations between the BMI and each of the urinalysis marker (the $\mathrm{pH}$, nitrites, blood, protein and glucose) with details in Table 3 (BMI and nitrites $\mathrm{p}=0.936$; $\mathrm{BMI}$ and protein $\mathrm{p}=1 ; \mathrm{BMI}$ and $\mathrm{pH}$ $\mathrm{p}=0.835$; BMI and blood, $\mathrm{p}=0.486$; respectively). There are no significant differences either on the 5 urinalysis markers between male and female groups $(\mathrm{p}>0.05)$.

Table 1. BMI and urinalysis markers among males and females

\begin{tabular}{ccccc}
\hline Variables & All & $\begin{array}{c}\text { Males } \\
(\mathrm{n}=74)\end{array}$ & $\begin{array}{c}\text { Females } \\
(\mathrm{n}=76)\end{array}$ & p-value \\
\hline Weight $(\mathrm{kg})(\mu(\mathrm{SD}))$ & $62.3(14.9)$ & $67.9(15.9)$ & $56.7(11.5)$ & $<0.001$ \\
Height $(\mathrm{cm})(\mu(\mathrm{SD}))$ & $162.1(8.3)$ & $168.2(5.8)$ & $156.1(5.6)$ & $<0.001$ \\
BMI $(\mathrm{kg} / \mathrm{m} 2)(\mu(\mathrm{SD}))$ & $23.6(4.8)$ & $23.9(5.1)$ & $23.3(4.5)$ & 0.411 \\
Underweight $(\mathrm{n}(\%))$ & $23(15.3)$ & $12(16.2)$ & $11(14.5)$ & 0.945 \\
Normal $(\mathrm{n}(\%))$ & $54(36)$ & $24(32.4)$ & $30(39.5)$ & 0.467 \\
Overweight $(\mathrm{n}(\%))$ & $27(18)$ & $8(10.8)$ & $19(25)$ & 0.040 \\
Obese I $(\mathrm{n}(\%))$ & $33(22)$ & $24(32.4)$ & $9(11.8)$ & 0.004 \\
Obese II $(\mathrm{n}(\%))$ & $13(8.7)$ & $6(8.1)$ & $7(9.2)$ & 1 \\
pH ( $\mu(\mathrm{SD}))$ & $5.8(0.7)$ & $5.7(0.7)$ & $5.8(0.6)$ & 0.445 \\
Normal $(\mathrm{n}(\%))$ & $75(50)$ & $32(43.2)$ & $43(56.6)$ & 0.142 \\
Increased $(\mathrm{n}(\%))$ & $20(13.3)$ & $11(14.9)$ & $9(11.8)$ & 0.761 \\
Decreased $(\mathrm{n}(\%))$ & $55(36.7)$ & $31(41.9)$ & $24(31.6)$ & 0.254 \\
Protein $(\mu(\mathrm{SD}))$ & $209.7(439.8)$ & $163.9(391.9)$ & $254.3(480.3)$ & 0.034 \\
Proteinuria $(\mathrm{n}(\%))$ & $149(99.3)$ & $74(100)$ & $75(98.7)$ & 1 \\
Nitrit $(+)(\mathrm{n}(\%))$ & $24(16)$ & $14(18.9)$ & $10(13.2)$ & 0.460 \\
Glucosuria $(\mathrm{n}(\%))$ & 0 & 0 & 0 & - \\
Hematuria $(\mathrm{n}(\%))$ & $8(5.3)$ & $2(2.7)$ & $6(7.9)$ & 0.293 \\
\hline
\end{tabular}

Table 2. Normal and abnormal urinalysis markers between males and females

\begin{tabular}{lcccc}
\hline \multicolumn{1}{c}{ Urinalysis } & \multicolumn{2}{c}{ Male $(\mathrm{n}=74)$} & \multicolumn{2}{c}{ Female $(\mathrm{n}=76)$} \\
\cline { 2 - 5 } \multicolumn{1}{c}{ Marker } & Normal $(\mathrm{n})$ & Abnormal $(\mathrm{n})$ & Normal $(\mathrm{n})$ & Abnormal $(\mathrm{n})$ \\
\hline $\mathrm{pH}$ & 32 & 42 & 43 & 33 \\
Nitrit & 60 & 14 & 66 & 10 \\
Glucose & 74 & 0 & 76 & 0 \\
Protein & 0 & 74 & 1 & 75 \\
RBC & 72 & 2 & 70 & 6 \\
\hline
\end{tabular}

RBC: red blood cell

Table 3. Chi-square test of obesity with urinalysis.

\section{DISCUSSION}

\begin{tabular}{lccc}
\hline \multicolumn{1}{c}{$\begin{array}{c}\text { Urinalysis } \\
\text { Marker }\end{array}$} & $\begin{array}{c}\text { P value } \\
\text { Overall (Male \& } \\
\text { Female) }\end{array}$ & $\begin{array}{c}\text { P value } \\
\text { Male }\end{array}$ & $\begin{array}{c}\text { P value } \\
\text { Female }\end{array}$ \\
\hline $\mathrm{pH}$ & 0.835 & 0.661 & 0.993 \\
Nitrit & 0.936 & 0.682 & 1 \\
Glucose & $\mathrm{a}$ & $\mathrm{a}$ & $\mathrm{a}$ \\
Protein & 1 & $\mathrm{~b}$ & 1 \\
Blood & 0.486 & 0.233 & 0.089 \\
\hline Note: a. No statistic are computed because glucose value is constant \\
\multicolumn{2}{l}{ b. No statistic are computed because protein value is constant }
\end{tabular}


Urinalysis examination by dipstick technique is a wellknown screening strategy for early detection of renal or urinary tract pathology in the seemingly healthy persons. As a semiquantitative test, however, the result of the dipstick tests should be taken with caution and clinical presentations should be taken into consideration (Lammers et al 2001, Smith et al 2003, Van Nostrand et al 2000). We found several cases in males and females with abnormal $\mathrm{pH}$, with detected proteinuria, haematuria and positive nitrites. Although no significant differences were found between these variables in male and female students; whilst no obvious correlations of these variables to the BMI.

Proteinuria, an exorbitant end of protein in the urine, may represent the tubular and/ or glomerular filtration function. This marker is generally correlated to the haematuria. However, haematuria may be due to totally different pathophysiology to the previous, as the later might be the result of bacterial infection, neoplasm, trauma, or others. In terms of proteinuria, the albuminuria is the most common source of proteinuria, which indicated the high possibility of renal function failure due to the epithelial damages of the urine filtration system in the cases of hypertension, diabetes mellitus type 2, and various cardiovascular diseases (Eidelman et al 2002, Lammers et al 2001, Van Nostrand et al 2000). Other factors that may produce proteinuria in asymptomatic persons include glomerular proteinuria and tubular proteinuria; glomerular proteinuria due to the increased glomerular capillaries permeability to allow great size of proteins such as albumin which leads into the nephrotic syndrome, reflux neuropathy, and various glomerulopathy; whilst the tubular proteinuria occurs due to the tubular resorption defect of small size proteins i.e. beta 2 microglobulin, tubular necrosis, and several hereditary tubulopathy (Chaudhari et al 2017, Simerville et al 2005, Srivastava \& Bagga, 2016).

Glycosuria occurs when the glucose levels overweight the filtration and/ or resorption capacity i.e. 180 to 200 $\mathrm{mg} / \mathrm{dL}$. These could be found in patients of diabetes mellitus, Cushing's disorder, liver and pancreatic impairment, and Fanconi's syndrome (Bono \& Reygaert, 2019, Chaudhari et al 2017, Simerville et al 2005). In the overweight and obese people, the kidney weight could be increased thus producing the glomerulomegaly, alterations on the podocytes, mesangial development, and the renal interstitium that would then undergo several degenerative processes i.e. fibrosis and microvascular impairment. Sodium homeostasis is interlinked with renal haemodynamics. High filtration fraction (FF), generally demonstrates high efferent vascular tone, that is related to blunted sodium discharge by diminishing peritubular hydrostatic. This may be the dominant underlying pathology in hypertension due to excessive salt diet intake (Xiang et al 2017). In terms of haematuria, the erythrocytes escape the renal filtration network. The dipstick test for blood identifies the peroxidase action of erythrocytes, which may be produced from the myoglobin or hemoglobin. Glucose is physiologically filtered by the glomeruli, and then totally reabsorbed in the proximal tubule. A study by Srinivasulu (2018) in Nellore, India however reported an isolated case of haematuria and proteinuria amongst the junior school children with no obvious pathologies (Srinivasulu et al 2018).

The $\mathrm{pH}$ and nitrites commonly used as a chemical marker of urinary tract infections. An increasing amount of nitrites could be the sign of the presence of pathological bacteria i.e Escherichia coli, Klebsiella sp., Serratia marcescens, Enterobacter sp.; and followed by $\mathrm{pH}$ modulation that indicating the existence of urea spitting bacteria (Bono \& Reygaert, 2019, Chaudhari et al 2017). In the overweight and obese persons, the excessive adipose tissue will contribute to the activation of the renin-angiotensin-aldosterone system (RAAS), which generates endothelial dysfunction and arterial stiffness, renal structural and functional changes, and physical compression (Bono \& Reygaert, 2019, Fountain \& Lappin, 2019, Hall et al 2018).

\section{CONCLUSION}

Urinalysis alterations are detected amongst seemingly healthy adolescent in the current study. Whilst there are no significant differences in the urinalysis marker levels between male and female students, there are positive correlations between the urinalysis marker protein and blood, also $\mathrm{pH}$ and blood.

\section{ACKNOWLEDGMENT}

Thank you to all participants and the IIKBW, Kediri. The authors declare that there is no conflict of interests.

\section{REFERENCES}

Bono MJ, Reygaert WC (2019). Urinary Tract Infection. In StatPearls. StatPearls Publishing: Treasure Island (FL). Available at https://www.ncbi.nlm.nih.gov/ books/NBK470195/\#article-30855.s4. Accessed May 22, 2019

Chaudhari PP, Monuteaux MC, Bachur RG (2017). Should the Absence of Urinary Nitrite Influence Empiric Antibiotics for Urinary Tract Infection in Young Children?: Pediatric Emergency Care : 1. 
Available at https://www.ncbi.nlm.nih.gov/pubmed/ 29135902. Accessed May 16, 2019

Cuzzo B, Lappin SL (2019). Vasopressin (Antidiuretic Hormone, ADH). In StatPearls. StatPearls Publishing: Treasure Island (FL). Available at: https://www.ncbi. nlm.nih.gov/books/NBK526069/. Accessed May 26, 2019

Eidelman Y, Raveh D, Yinnon AM, Ballin J, Rudensky B, Gottehrer NP (2002). Reagent strip diagnosis of UTI in a high-risk population. The American Journal of Emergency Medicine 20: p 112-113.

Fountain JH, Lappin SL (2019). Physiology, Renin Angiotensin System. In StatPearls. StatPearls Publishing: Treasure Island (FL). Available at https://www. ncbi.nlm.nih.gov/books/NBK470410/. Accessed May 22, 2019.

Gant CM, Minovic I, Binnenmars H, de Vries L, Kema I, van Beek A et al (2018). Lower Renal Function Is Associated With Derangement of 11- 3 Hydroxysteroid Dehydrogenase in Type 2 Diabetes. Journal of the Endocrine Society 2, 609-620

Hall ME, Wang Z, do Carmo J, Kamimura D, Hall JE (2018). Obesity and Metabolic Syndrome Hypertension. In Disorders of Blood Pressure Regulation, Berbari AE and Mancia G (eds). Springer International Publishing, Cham, p 705-722

Hewagalamulage SD, Lee TK, Clarke IJ, Henry BA (2016). Stress, cortisol, and obesity: a role for cortisol responsiveness in identifying individuals prone to obesity. Domestic Animal Endocrinology 56, S112S120

Lammers RL, Gibson S, Kovacs D, Sears W, Strachan G (2001). Comparison of test characteristics of urine dipstick and urinalysis at various test cutoff points. Annals of Emergency Medicine 38, 505-512

Scott JH, Dunn RJ (2019). Physiology, Aldosterone. In StatPearls. StatPearls Publishing: Treasure Island (FL). Available at https://www.ncbi.nlm.nih.gov/ books/NBK470339/. Accessed May 132019.

Simerville JA, Maxted WC, Pahira JJ (2005). Urinalysis: a comprehensive review. American Family Physician 71, 1153-1162

Smith P, Morris A, Reller LB (2003). Predicting urine culture results by dipstick testing and phase contrast microscopy. Pathology 35, 161-165

Srinivasulu K, Rao KVP, Kumar KP (2018). Urine Analysis as a Screening Tool in Early Detection of Renal Abnormalities in Asymptomatic School Children. World Journal of Nephrology and Urology 7, 17-24

Srivastava RN, Bagga A (eds) (2016). Pediatric nephrology. Sixth edition. Jaypee Brothers Medical Publishers (P) LTD: New Delhi, Philadelphia, p 273300

Van Nostrand JD, Junkins AD, Bartholdi RK (2000). Poor predictive ability of urinalysis and microscopic examination to detect urinary tract infection. American Journal of Clinical Pathology 113, 709-713

Xiang DM, Song XZ, Zhou ZM, Liu Y, Dai XY, Huang XL, Hou FF, Zhou QG (2017). Chronic kidney disease promotes chronic inflammation in visceral white adipose tissue. American Journal of Physiology-Renal Physiology 312, F689-F701

Zoccali C, Mallamaci F (2011). Does adipose tissue have a key role in inflammation in CKD?: Editorial: CKD, inflammation and the adipose tissue. Journal of Internal Medicine 269, 407-409 